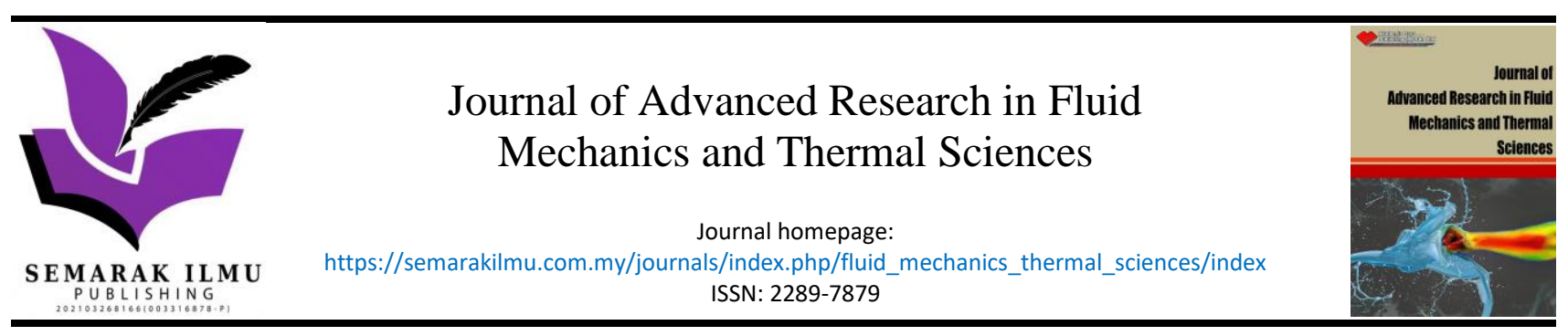

\title{
Influence of Environment-Friendly Fuel Additives and Fuel Injection Pressure on Soot Nanoparticles Characteristics and Engine Performance, and NOX Emissions in $\mathrm{Cl}$ Diesel Engine
}

\author{
Mohammed A. Fayad ${ }^{1,}{ }^{*}$, Amera A. Radhi ${ }^{1}$, Salman Hussien Omran ${ }^{1}$, Farag Mahel Mohammed ${ }^{2}$ \\ Energy and Renewable Energies Technology Center, University of Technology-Iraq, Baghdad, Iraq \\ Electromechanical Engineering Department, University of Technology-Iraq, Baghdad, Iraq
}

\section{ARTICLE INFO}

\section{Article history:}

Received 13 April 2021

Received in revised form 20 September 2021

Accepted 23 September 2021

Available online 12 October 2021

\section{Keywords:}

Biodiesel; BTE; BSFC; soot nanoparticles; TEM; NOX emissions

\section{ABSTRACT}

\section{Introduction}

The objectives of the world are substituting fossil fuels by alternative fuels to reducing the pollutant emissions to meet the standard emissions regulations. It well known that the compression ignition $(\mathrm{Cl})$ engine produces high level of soot and $\mathrm{NO}_{\mathrm{x}}$ emissions that effect on both environment and health [1]. To confront technology, climate, and renewability challenges, different blends of fuels derived from a large variety of feedstock will be available in the future such as biodiesel-diesel blends and alcohol-diesel blends. Recently, the world's depending on use of biodiesel as alternative to conventional petroleum resources due to its environmentally friendly solution, positive health

\footnotetext{
* Corresponding author.

E-mail address: Mohammed.A.Fayad@uotechnology.edu.iq
}

https://doi.org/10.37934/arfmts.88.1.5870 
effects, and increasing popularity of alternative fuels [2,3]. It is reported that co-firing palm oil waste with coal can reduces the $\mathrm{SO}_{x}, \mathrm{NO}_{x}$, and greenhouse gas [4]. Also, it considered a cost-effective option with the rapid depletion of fossil fuel reserves over the world. The effects of alternative fuels on performance and emissions of diesel engines have been extensively reviewed in previous studies $[5,6]$. In terms of emissions, stringent environmental regulations Increased on $\mathrm{NO} \times$ and PM encourage the authors to development the new generation fuels. Therefore, many studies have been documented on results of $\mathrm{NO}_{x}$ and PM emitted from the oxygenated fuels combustion in diesel engines [7,8]. Zulkurnai et al., [9] stated that the $\mathrm{NO}_{\mathrm{x}}$ and soot decreased from combustion of ethanol-diesel blend which contribute in better engine performance and better environmental future. Most of studies reported that the soot emissions decreased as the percentage of biodiesel content increased in the fuel-blend [10]. PM emissions decreased by $73-83 \%$ from the combustion of three pure methyl esters such as methyl-palmitate, methyl-oleate, and methyl-laurate compared with diesel fuel combustion as presented in Knothe et al., [11]. They found that this trend due to the absence aromatic compounds in biodiesel compared that are present in diesel fuel. The impacts of alternative fuels formulation on soot characteristics were investigated, especially for soybeanderived biodiesel and alcohol-diesel blends [12]. They suggested that the important factor influencing the oxidation rate is surface oxygen content. The oxidative reactivity of soot and combustion process are affected by the fuel composition and the engine operating parameters [13]. In single-cylinder diesel engine, different ethanol percentages generated the soot particles with a similar nanostructure compared to the diesel soot. It was found that the oxygenated fuels increase the soot reactivity of particulate matter (PM) at high concentration of oxygen content in fuel properties [14]. In addition, higher active surface area of soot particles was observed during the combustion of alcohol-diesel blends [15]. The sooting propensities of hydrocarbon fuels have been studied by Westbrook et al., [16] for oxygenated fuels additives. It was found that the sooting propensity decreased from the oxygenated functional groups (ethers, esters, and alcohols). The effect of addition oxygenates into the fuel on the suppression of the sooting propensity have been modelled by Westbrook et al., [16] in diesel engines. The soot formation can be initiated due to the lack of oxygen in the fuel-rich premixed flame ignition followed by quenching. It is reported that the high injection pressure increases the oxidation rate of soot particles and promotes the soot reactivity [17]. Prior works has been reported that oxygenated fuels (i.e., fuel-bonded oxygen) decreased that the soot emissions and improved the combustion characteristics [18]. It is reported that the soot particles have different oxidative reactivity and nanostructural order from the combustion of acetylene, Benzene, and ethanol [19]. More reactive and a more amorphous structure of soot particles were found from Benzene compared with acetylene. It is stated that the soot particles formed as aggregate structures or single particle according to the images of transmission electron microscopy (TEM) [20]. The morphological properties of soot particles are diameter of primary particles $\left(n_{p o}\right)$, number of primary particles $\left(n_{p o}\right)$ and size of primary particles $\left(d_{p o}\right)$. In previous work, it was observed that the using a bioethanol-diesel blend can be decrease the PM in diesel engine. This trend related to the various factors of fuel properties such as reduced aromatic content, fuel-borne oxygen, and lower fuel $\mathrm{C} / \mathrm{H}$ mass ratio. As shown in the literature, the nanostructure of soot particles depends on the residence time and temperature [21]. At high temperature, the size of soot particle decreased because of the higher rate of soot particles oxidation [22]. It is stated that the soot aggregate sizes and spherule increased during the high condition of engine conditions of exhaust temperature and engine load. Due to the shorter resident time of particle surface growth, the size of soot particles is smaller under higher engine speed [23]. The engine parameters of injection pressure, temperature, engine load and speed, and injection timing are effect on soot formation [24]. It is reported FIP is important parameter of engine operating conditions that effect on the soot emissions and engine 
performance [25]. Increasing FIP and using alternative fuels are a good way to inhibit the soot formation and reduce engine emissions in diesel engine [26,27]. Agarwal et al., [27] stated that the smaller size of PM is more harmful for human health and environment. Harris and Maricq [28] reported that the large soot particles decreased with increasing FIP. To comply with the stringent global emission, FIP is efficient ways to achieve these requirements. High fuel injection pressures can reduce the PM emissions and keep $\mathrm{NO}_{x}$ emissions in moderate level [29]. It is reported that combination of high injection pressure and biodiesel leads produce lower level of smoke opacity and engine emissions $[26,30]$. The complicated nature of soot particles formation leads to more studies about the characteristics of soot particles. The details of the combined effect of alternative fuel and injection pressure on the soot emissions in the literature were much more limited. Therefore, the present work addresses the impacts of alternative fuel additives on characteristics of soot nanoparticles and engine performance in $\mathrm{Cl}$ diesel engine. Furthermore, study the effect of fuel injection pressure (FIP) on the soot nanoparticles characteristics $\left(n_{p o}\right.$ and $\left.d_{p o}\right)$ ) for all fuels tests.

\section{Experimental}

\subsection{Engine Setup}

During experiments, four-cylinder, direct injection diesel engine was employed as shown in Figure 1. Table 1 listed the main characteristics of the research engine. To generate load, eddy current dynamometer was used by equipped with engine. LabView program was used to manage the timebased data acquisition. A series of National Instruments FieldPoint modules were used to read the analog signals from thermocouples, pressure transducers, and emissions data. In each test, the FieldPoint modules is collecting the data every $1 \mathrm{~s}$ during a 3-min period. The pressure transducers (AVL GU12P) were used to measure the pressure traces. The signal from the pressure transducers was amplified using Kistler type 5010. At a resolution of 0.1 crank angle degrees, the traces of pressure were recorded and averaged over 200 cycles. The data of pressure trace was used to calculate the ROHR using a thermodynamic diagnostic model.

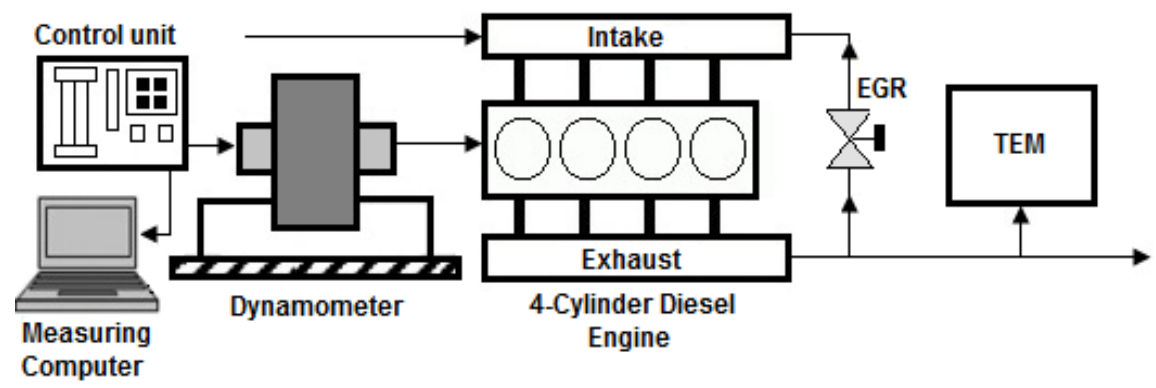

Fig. 1. Schematic of the experimental installation

Table 1

Characteristics of diesel engine

\begin{tabular}{ll}
\hline Parameters & Specifications \\
\hline Engine type & Diesel engine \\
Cylinders number & 4 \\
Bore $(\mathrm{mm})$ & 84 \\
Stroke $(\mathrm{mm})$ & 90 \\
Rod length $(\mathrm{mm})$ & 162 \\
Compression ratio & 16.1 \\
Displacement (cc) & 499 \\
Engine speed range (rpm) & 2000 \\
Maximum rated torque & $320 \mathrm{Nm}$ at $1800 \mathrm{~min}^{-1}$ \\
\hline
\end{tabular}




\subsection{Test Fuels and Equipment}

In the current work, three different fuels were used to produce a variety of soot emissions in the exhaust. The baseline fuel and alternative fuel were diesel fuel and ethanol-blend, respectively. The biodiesel is produced from the castor oil as renewable sources. The fuel blend is prepared by mixing $70 \%$ of diesel and $30 \%$ of castor oil (C30D). The property information and specifications of tests fuels were listed in Table 2. The water-cooling system was used to control and monitor the fuel temperature for all fuels tests. The exhaust gas emissions analyser (type AVL 444) with recording software was used to measure the engine emissions $\left(\mathrm{NO}_{\mathrm{X}}\right)$. The soot nanoparticles characteristics were investigated using a 200-kV field-emission transmission electron microscopy (TEM). The highresolution bright images of soot nanoparticles were taken by TEM. At high magnification $(500,000)$ of TEM has been adjusted for all images of soot samples. The ultrasonically was used to disperse soot samples soot samples for $60 \mathrm{~min}$ [31]. This method was used by Al-Qurashi and Boehman [32]. Matlab software was used to analyse the characteristics of soot particles [20]. The engine operating conditions were 1800 rpm, 4 bar, for engine speed and IMEP, respectively. The FIP was 550 bar and 1000 bar to study the effect of fuel formulation and injection strategy on the soot nanoparticles characteristics of diesel engine.

Table 2

Properties of diesel fuel and C30D

\begin{tabular}{lll}
\hline Properties & Diesel & C30D \\
\hline Cetane Number & 53.2 & - \\
Bulk Modulus (MPa) & 1410 & 1564 \\
Density at $15{ }^{\circ} \mathrm{C}\left(\mathrm{kg} / \mathrm{m}^{3}\right)$ & 824.1 & 864.2 \\
Kinematic Viscosity at $40{ }^{\circ} \mathrm{C}(\mathrm{cSt})$ & 2.7 & 4.26 \\
Lower Calorific Value $(\mathrm{MJ} / \mathrm{kg})$ & 42.11 & 40.73 \\
Upper heating value $(\mathrm{MJ} / \mathrm{kg})$ & 44.5 & 43.62 \\
Lubricity at $60{ }^{\circ} \mathrm{C}(\mu \mathrm{m})$ & 312 & 202 \\
$\mathrm{C}($ wt\%) & 87.24 & 81.13 \\
$\mathrm{H}($ wt\%) & 14.86 & 12.87 \\
$\mathrm{O}($ wt\%) & 0 & 5.16 \\
$90 \%$ Distillation $\left({ }^{\circ} \mathrm{C}\right)$ & 329 & 342 \\
\hline
\end{tabular}

\section{Results and Discussion}

\subsection{Size Distribution of Soot Particulate}

The size distributions of soot particulate are measured for C30D and diesel under 500 bar and 1000 bar of FIP as shown in Figure 2. It can be seen that soot particle number concentration decreased with high injection pressure for C30D and diesel fuel. This could have been due to the enhance air-fuel mixing and smaller droplet of fuel that causes a better oxidation rate of soot particulate. These results are agreement with previous studies [33,34]. A comparison of fuels, it can be observed that the size distribution of soot particles decreased from C30D combustion by $43.62 \%$ compared to the diesel as depicted in Figure 2. Furthermore, the distributions were displaced towards lower diameter values and decreased and the total concentration of particulate decreased during the combustion of C30D compared with the diesel. It is suggested that the higher viscosity and higher oxygen content of C30D could be effect on particle number concentration [35]. Saxena et al., [36] reported that the biodiesel decreased the total particle number concentration compared to the conventional diesel fuel. Also, lower particle number concentration (38\%) produced from biodiesel compared to the diesel [37]. The combustion of C30D decreased the size distribution of soot particles 
for both conditions of FIP compared with diesel. In addition, the soot precursor species production can be reduced depending on the ester structure of castor oil [38]. Figure 2 show that the high injection pressure and higher viscosity of biodiesel and lead to better fuel atomization, which decreased the total number of soot particles. Fayad [12] reported that the insufficient oxygen to burn the fuel and fuel-rich premixed ignition are promote the soot formation during the combustion process. The better fuel atomization and spray characteristics with high injection pressure and higher density of C30D could be decrease the particle number emission $[39,40]$. It can be observed that the size distribution of soot particulate shifted to the nucleation mode with 1000 bar compared with 500 bar (accumulation mode) as shown in Figure 2.

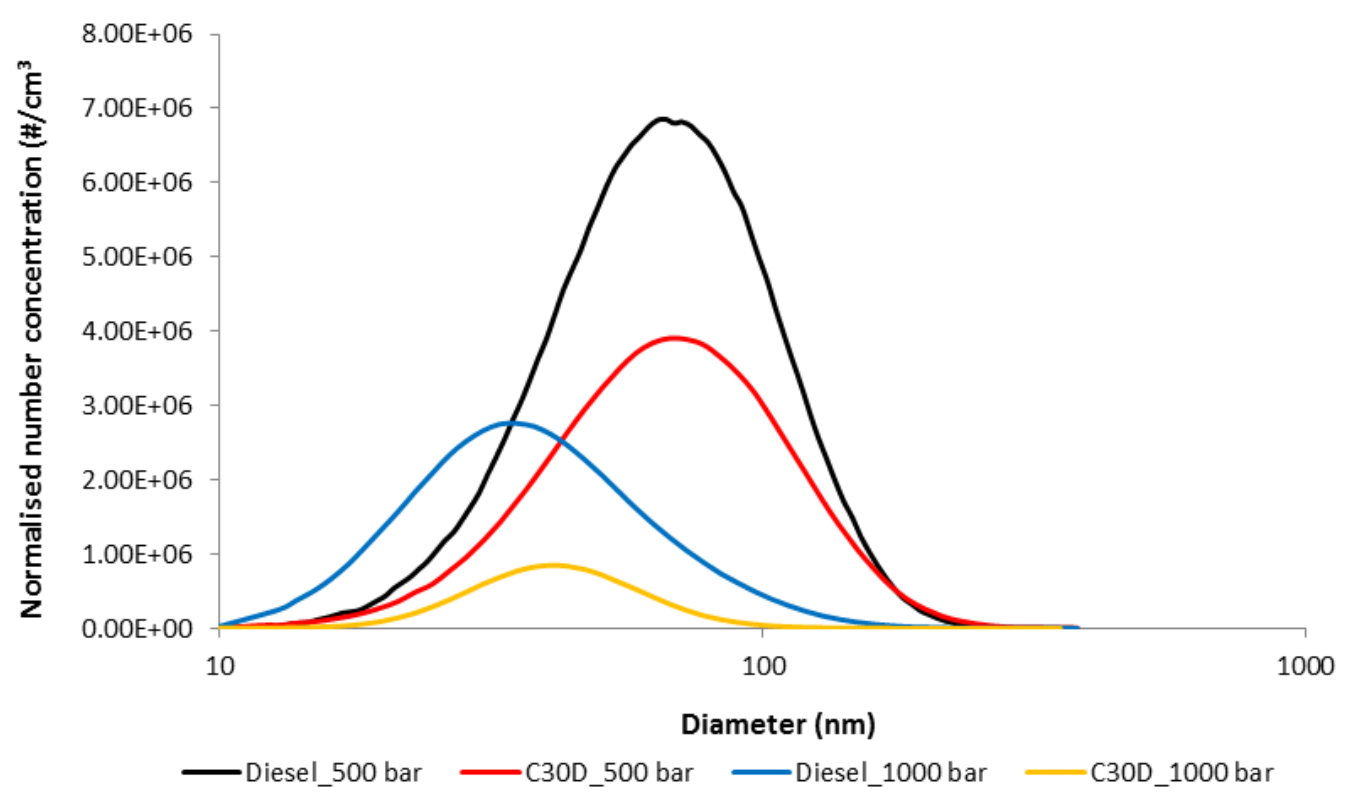

Fig. 2. Effect of FIP and C3OD on size distribution of soot nanoparticles

\subsection{Number of Soot Primary Particle $\left(n_{p o}\right)$}

Figure 3 presents the effect of C30D and different fuel injection pressures on number of primary particle $\left(n_{p o}\right)$. The results from this figure show that the C30D combustion decreased the number of primary particles $\left(n_{p o}\right)$ compared with diesel combustion. Figure 5 gives general characteristics of soot agglomeration can be measured through analysis TEM images. The average number of primary particles decreased from C30D combustion by $44.35 \%$ compared with diesel for different FIP. The oxygen content in $\mathrm{C} 30 \mathrm{D}$ and incorporation of the injection pressure leads to boost the oxidation rate of soot particles result in decreasing the total number of particulates. In addition, the effective combustion of C30D has high potential in reducing the number of soot primary particle by increasing the oxidation rate during the combustion. From the literatures, it was found that oxygen-born in the biodiesel contributes in more complete combustion and decrease the soot particles number because the available oxygen in the combustion region [41,42]. Furthermore, the reduction in number of particles could be due to the decrease the collisions of soot particles and more aggregation. The increase FIP of 1000 bar inhibited $n_{p o}$ by $11.6 \mathrm{~nm}$ and $25.4 \mathrm{~nm}$ compared with 500 bar by $22.4 \mathrm{~nm}$ and 33.2 from C3OD and diesel, respectively, as shown in Figure 3. It is thought that FIP associated with decreases the resident time for soot formation and decreases the soot precursors formation into the cylinder $[13,43]$. 


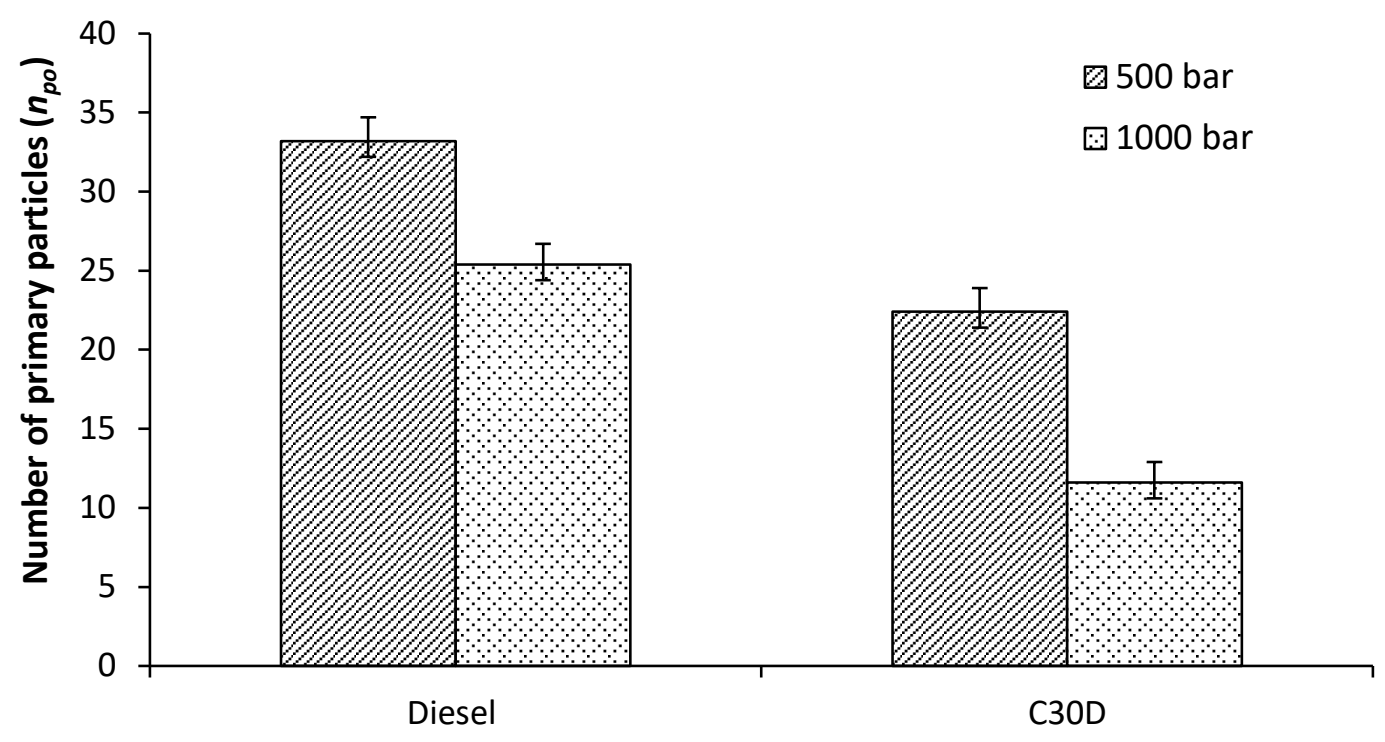

Fig. 3. Effect of FIP and C30D on number of primary particles $n_{p o}$

\subsection{Diameter of Soot Primary Particles $\left(d_{p o}\right)$}

It is well known that the important parameter to evaluate health and environmental effects is size of soot particles [44]. The smaller size of soot particles is more potentially be suspended a longer time in the air, while the larger size of soot particles is more reactive. Thus, these smaller particles can penetrate into the alveolar regions and bronchi. The results of $d_{p o}$ were found according to the TEM images in Figure 5 using Matlab code. The diameter of soot primary particles $\left(d_{p o}\right)$ from combustion of C3OD and diesel is shown in Figure 4 for different FIP. According to the Figure 4, the C30D decreased the average $d_{p o}$ by $47.68 \%$ compared with diesel for both conditions of FIP. The main reasons for that are lower rate of soot production, soot growth, and soot formation as well as enhance the oxidation rate of soot particles during the combustion of C30D. These results are highly similar with results obtained by previous studies for biodiesel and butanol blends $[12,20,45,46]$. It can be observed that the increasing the injection pressure decreased the average $d_{p o}$ compared for both fuels (Figure 4). The shorten time of soot growth and improved soot oxidation rate (high combustion temperature) under high FIP leads to produce smaller $d_{p o}$ during the combustion process.

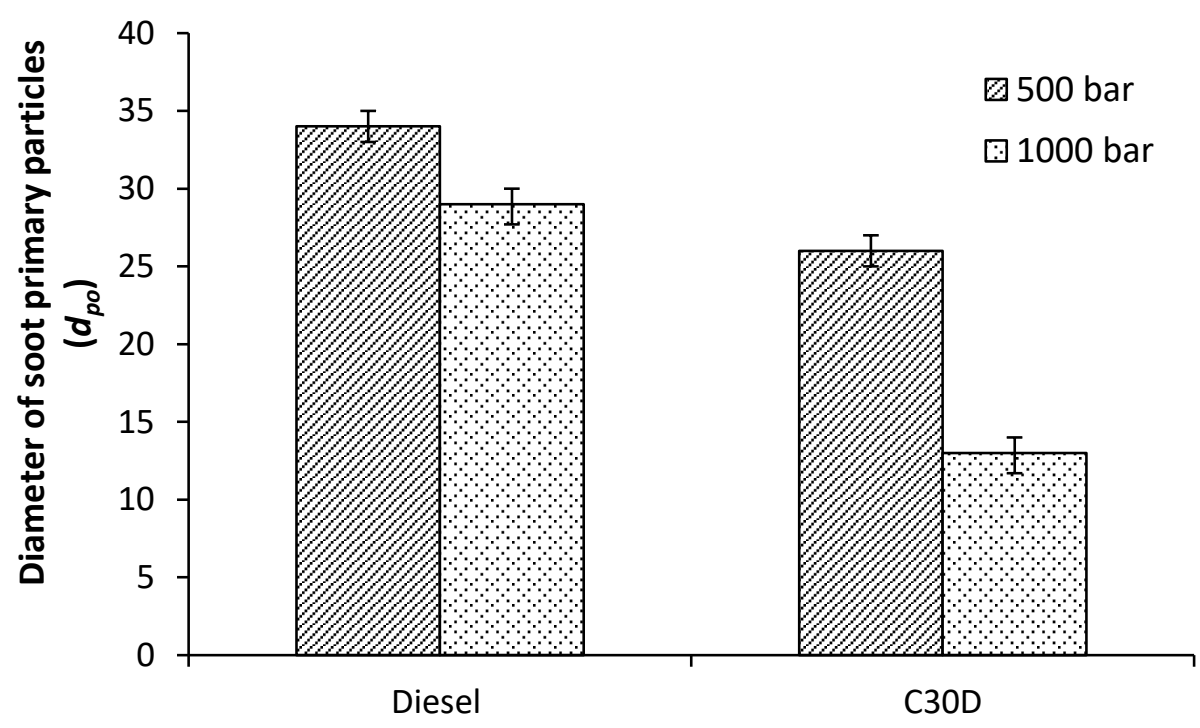

Fig. 4. Effect of FIP and C3OD on diameter of primary particles $d_{p o}$ 

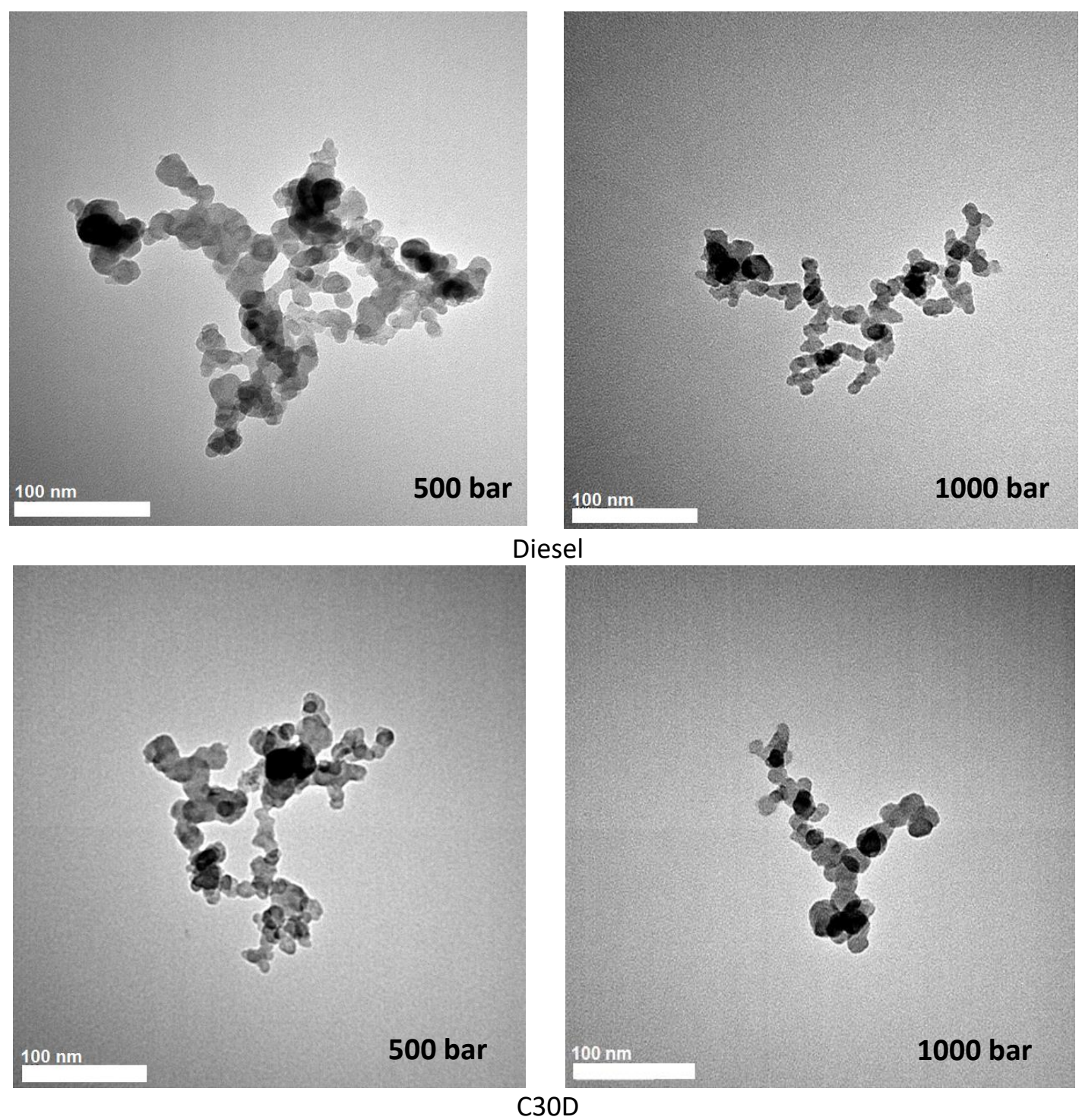

Fig. 5. Soot agglomerates images for diesel fuel and C30D under 500 bar and 1000 bar of injection pressure

\subsection{Brake Thermal Efficiency and Brake Specific Fuel Consumption}

The effects of C3OD and FIP on BTE are shown in Figure 6. I can be found that the BTE increased during the combustion of C30D by $32.5 \%$ compared with diesel by $30.4 \%$ for different FIP. The higher oxygen content of C3OD compared with diesel causes complete combustion which improves the thermal efficiency. It is reported that the BSFC and LHV are a function of improve the thermal efficiency $[12,47]$. Also, it is mentioned that BTE increased with increasing the biodiesel in the fuel blend due to increase the oxygen content in the fuel blend [48]. The combustion efficiency increased from these effects. In case of infection pressure, the increasing FIP slightly improve the BTE for both fuels. Furthermore, the BTE increased with 1000 bar by $34.3 \%$ and $32.6 \%$ compared with 500 bar by $30.7 \%$ and $28.8 \%$ for C3OD and diesel fuel, respectively. 


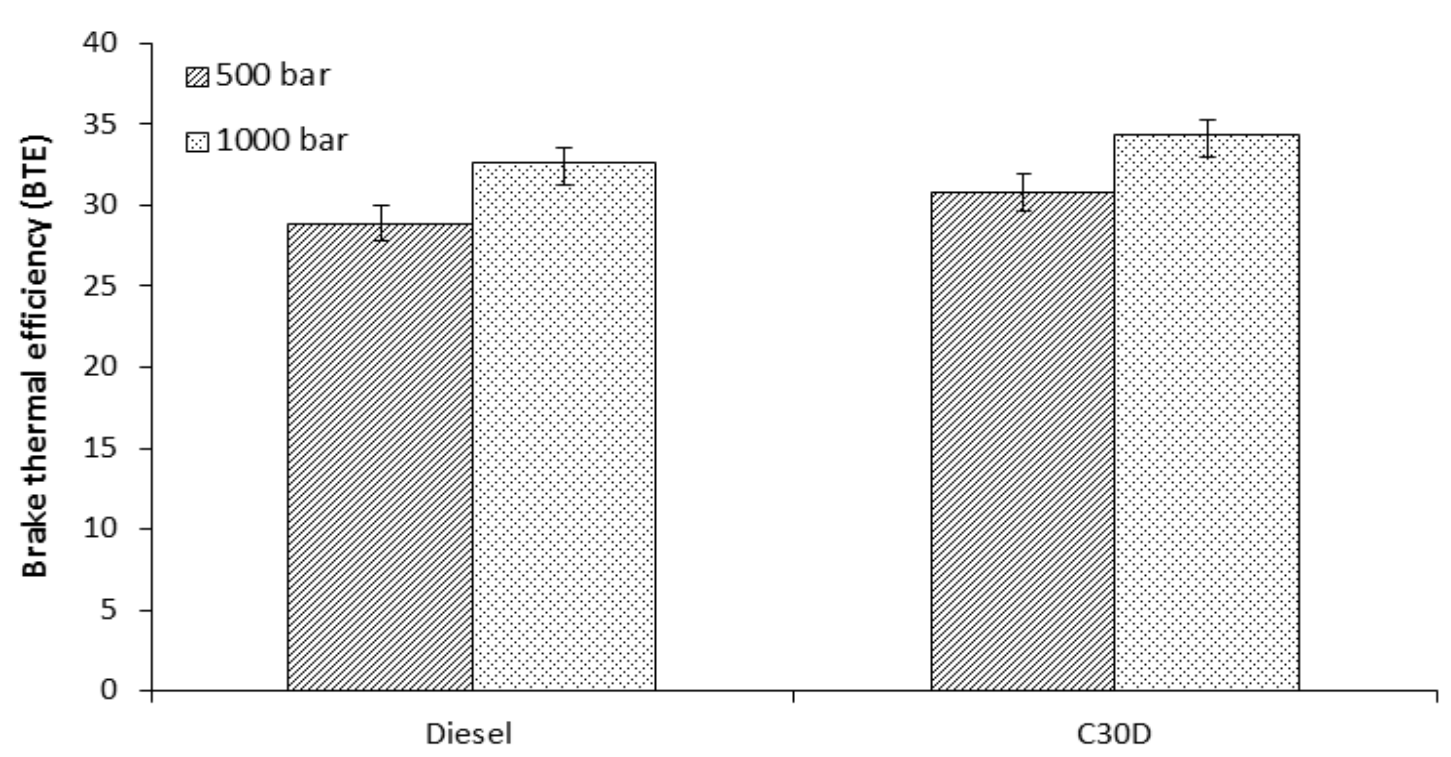

Fig. 6. Effect of FIP and C3OD on brake thermal efficiency (BTE)

The influences of C30D and FIP on the BSFC are presented in Figure 7. It can be seen that the C30D combustion increase the BSFC compared diesel for 500 bar and 1000 bar of injection pressure. The lower heating value and calorific Value of C30D lead to increase the BSFC, which is consistent with previous study [13]. In addition, similar results were found by other authors $[49,50]$. For all fuels, the similar trend was observed with FIP as shown in Figure 7. Furthermore, it can be noticed that the BSFC decreased with 1000 bar of fuel injection pressure compared with 500 bar for both fuels. The smaller fuel particle diameters and slight delay admission during the combustion result in decrease the BSFC [47]. At higher FIP, the BSFC decreased due to the better fuel atomization and lesser fuel going to cylinder [51]. On the other hand, longer ignition delay and enlarge of fuel particle diameter with 500 bar of FIP causes higher BSFC. The values of BSFC decreased by $0.2348 \mathrm{~kg} / \mathrm{kW} \mathrm{h}$ and 0.21485 $\mathrm{kg} / \mathrm{kW} \mathrm{h}$ for 1000 bar and increased by $0.2948 \mathrm{~kg} / \mathrm{kW} \mathrm{h}$ and $0.2549 \mathrm{~kg} / \mathrm{kW}$ h during the combustion of C30D and diesel, respectively.

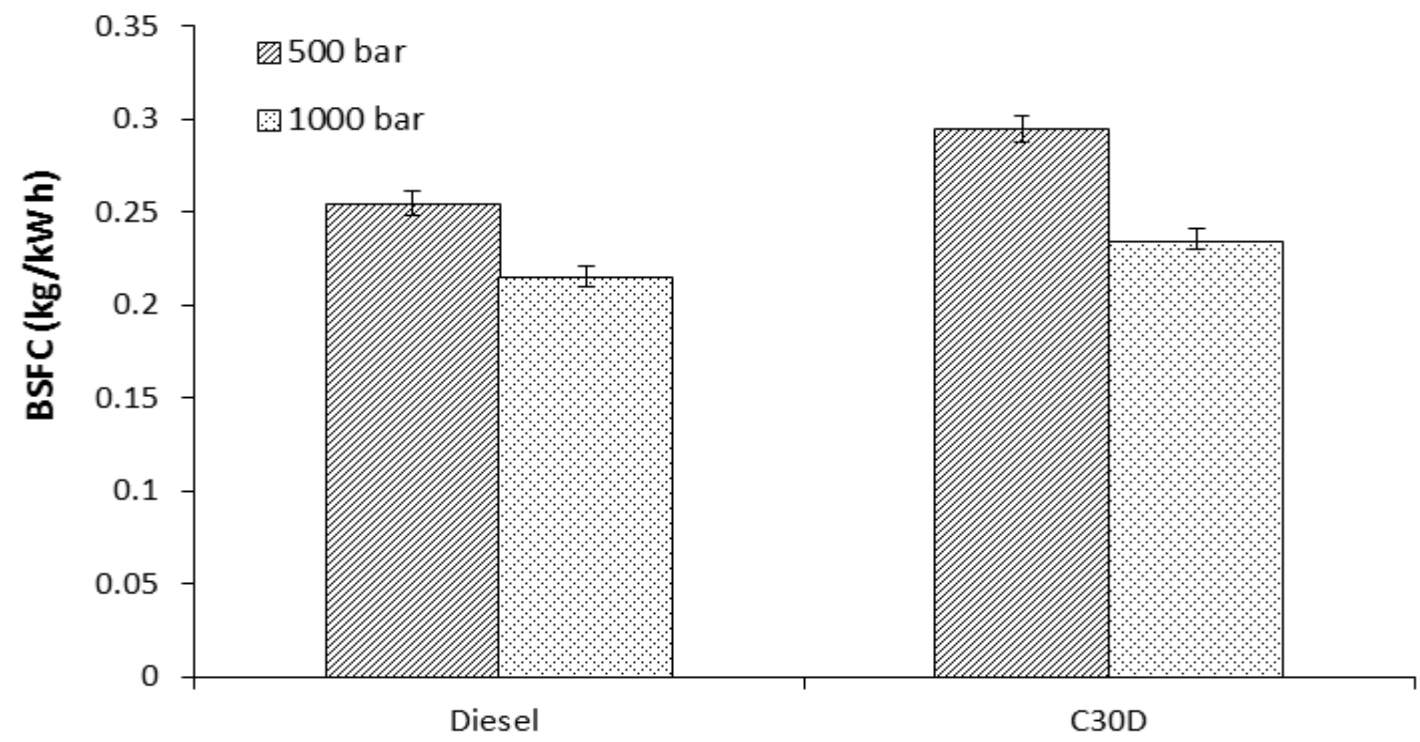

Fig. 7. Effect of FIP and C3OD on brake specific fuel consumption (BSFC) 


\subsection{Exhaust Gas Temperature (EGT)}

Figure 8 depicts the effect of C30D and diesel fuel on EGT for 500 bar and 1000 bar of FIP. As observed in this figure, the EGT increased from the combustion of C3OD and diesel with increasing the FIP. This could be due to the faster combustion rates from increasing the FIP which result in an increase the EGT (Figure 8) [13]. A comparison of fuels, the EGT significantly increased during the C30D combustion compared with diesel for variable FIP as presented in Figure 8. The EGT was enhanced due to the presence oxygen-born in castor oil properties (Table 2) which improved the combustion temperature and pressure [20,52]. The mixture of fuel-air could be improved due to increasing the injection pressure from 500 bar to the 1000 bar, which in turn leads to complete combustion [53]. In addition, high injection pressure produces smaller droplets of fuels and enhances the fuel distribution to reach the better combustion.

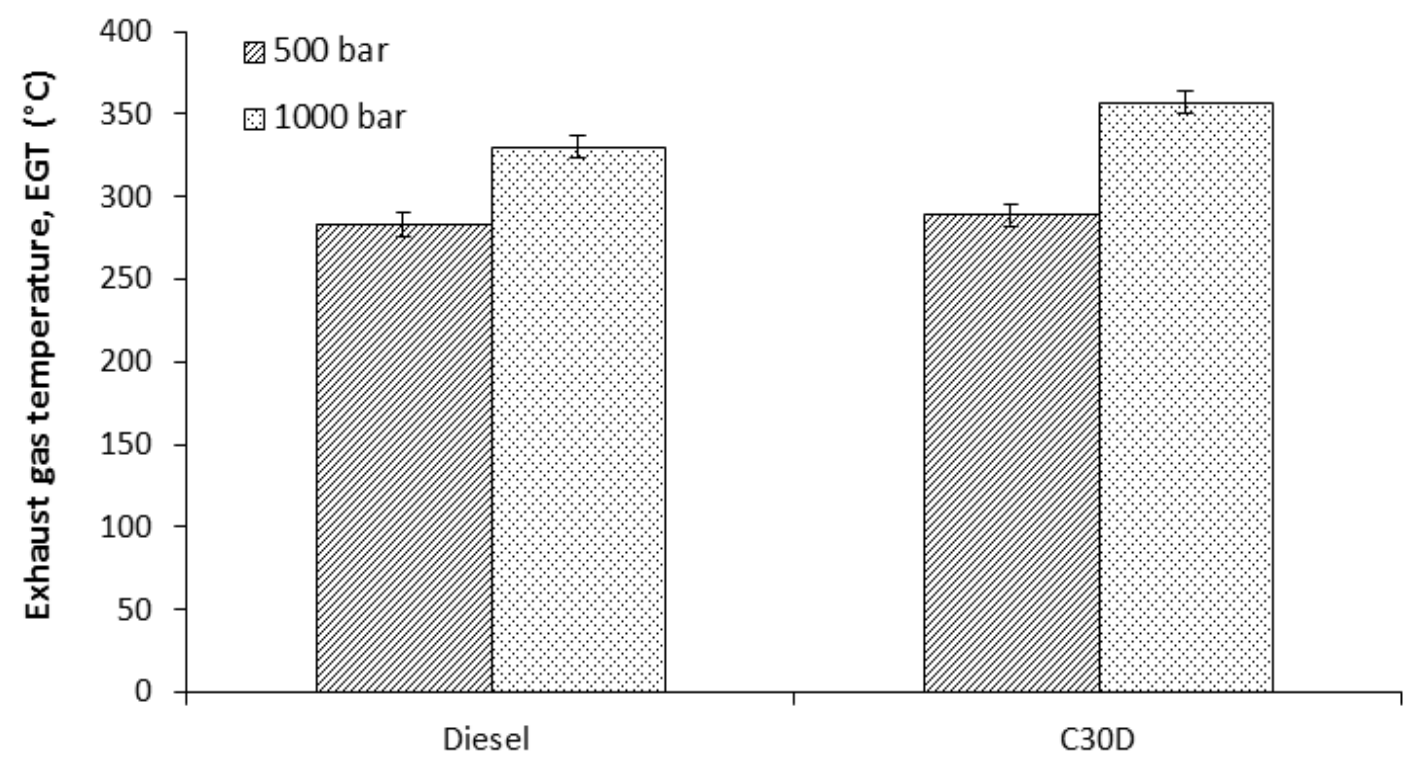

Fig. 8. Effect of fuel injection pressure and C3OD on exhaust gas temperature (EGT)

Figure 9 shows the results of $\mathrm{NO}$ x emissions for $\mathrm{C} 30 \mathrm{D}$ and diesel under both conditions of FIP. In general, the $\mathrm{NO}_{x}$ emissions for $\mathrm{C3OD}$ and diesel with increasing the FIP as presented in Figure 9. This is due to increase the combustion temperature (Figure 8) with high injection pressure, as a consequence starts $\mathrm{NO}$ emissions increase [26]. The fuel particle diameter decreased with high FIP result in an increase of combustion temperature, which in turn increases the $\mathrm{NO}_{x}$ formation. For both FIP, the NOx emissions increased during the combustion of C30D by $17.62 \%$ than to the diesel (Figure 7). This could have been due to the oxygen content in C3OD that enhance the formation of NOx emissions [54,55]. Prior work reported that the chemically bound oxygen content in oxygenated fuels promote the $\mathrm{NO} x$ formation [56]. The current results are agreement with previous experimental studies that cited in the introduction and results. 


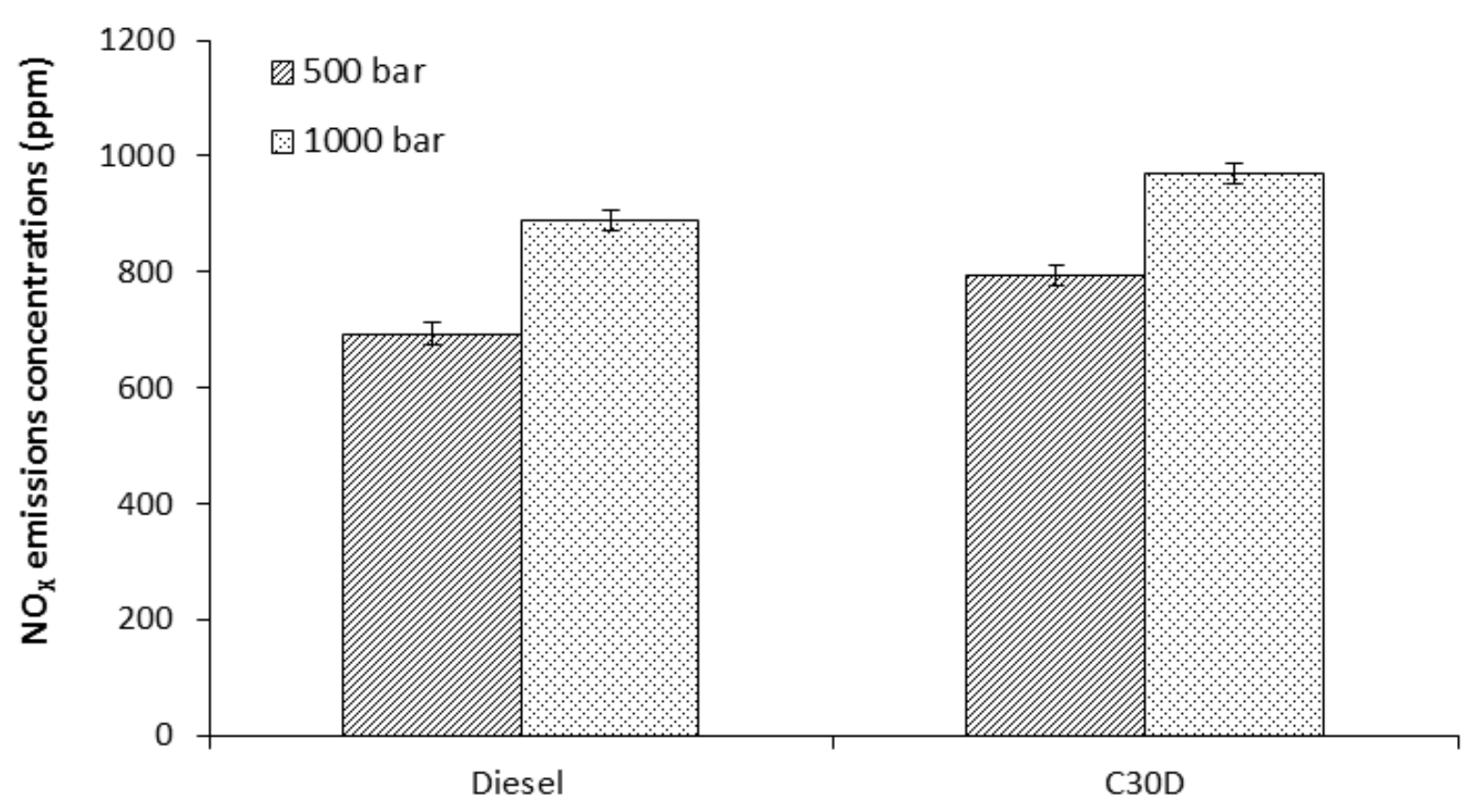

Fig. 9. Effect of FIP and C3OD on $\mathrm{NO}_{x}$ emissions

\section{Conclusions}

The influences of C30D and fuel injection pressures of DI diesel engine on soot nanoparticles characteristics and $\mathrm{NO}_{\mathrm{x}}$ emissions were experimentally investigated in this study. The main conclusions of this experimental research were summarized as follows

i. It can be concluded that the characteristics of soot nanoparticles decreased from C3OD combustion compared to the diesel for different conditions of FIP.

ii. The oxygen content in $\mathrm{C} 30 \mathrm{D}$ contributes in a significant reduction in size distribution of soot particles by $43.62 \%$ compared to the diesel under 500 bar and 1000 bar of FIP.

iii. For both FIP, it was observed that the $n_{p o}$ and $d_{p o}$ decreased by $44.35 \%$ and $47.68 \%$ during the combustion of C30D compared to the diesel, respectively.

iv. The high FIP of 1000 bar decreased the soot characteristics of $n_{p o}$ (by $11.6 \mathrm{~nm}$ and $25.4 \mathrm{~nm}$ ) and $d_{p o}$ (by 13 and 29) for C30D and diesel, respectively.

v. It was found that BTE and BSFC increased from C30D combustion compared diesel, while high injection pressure improves the fuel economy and thermal efficiency for both fuels.

vi. The NOx emissions slightly increased $17.62 \%$ from C30D combustion compared diesel for 500 bar and 1000 bar of FIP.

vii. The effects of C3OD and high injection pressure were decreased the soot nanoparticles characteristics and improves the engine performance.

viii. It was found that these results will be beneficial for improve the efficiency of aftertreatment catalyst in diesel engines.

\section{References}

[1] Zulkurnai, Fatin Farhanah, Norhidayah Mat Taib, Wan Mohd Faizal Wan Mahmood, and Mohd Radzi Abu Mansor. "Combustion Characteristics of Diesel and Ethanol Fuel in Reactivity Controlled Compression Ignition Engine." Journal of Advanced Research in Numerical Heat Transfer 2, no. 1 (2020): 1-13.

[2] Kaewbuddee, Chalita, Ekarong Sukjit, Jiraphon Srisertpol, Somkiat Maithomklang, Khatha Wathakit, Niti Klinkaew, Pansa Liplap, and Weerachai Arjharn. "Evaluation of waste plastic oil-biodiesel blends as alternative fuels for diesel engines." Energies 13, no. 11 (2020): 2823. https://doi.org/10.3390/en13112823 
[3] Ramlan, N. A., A. A. Abdullah, and W. J. Yahya. "Combustion Performance and Exhaust Emission Analysis of Diesel Engine using Waste Cooking Oil." Journal of Advanced Research in Fluid Mechanics and Thermal Sciences 12, no. 1 (2015): 11-20.

[4] Yacob, Noraishah Shafiqah, Hassan Mohamed, and Abd Halim Shamsuddin. "Investigation of Palm Oil Wastes Characteristics for Co-Firing with Coal." Journal of Advanced Research in Applied Sciences and Engineering Technology 23, no. 1 (2021): 34-42. https://doi.org/10.37934/araset.23.1.3442

[5] Shameer, P. Mohamed, Kasimani Ramesh, Rajamohan Sakthivel, and Ramakrishman Purnachandran. "Effects of fuel injection parameters on emission characteristics of diesel engines operating on various biodiesel: a review." Renewable and Sustainable Energy Reviews 67 (2017): 1267-1281. https://doi.org/10.1016/i.rser.2016.09.117

[6] Fayad, Mohammed A. "Investigation the impact of injection timing and pressure on emissions characteristics and smoke/soot emissions in diesel engine fuelling with soybean fuel." Journal of Engineering Research 9, no. 2 (2021): 296-307. https://doi.org/10.36909/jer.v9i2.9683

[7] Durbin, Thomas D., and Joseph M. Norbeck. "Effects of biodiesel blends and Arco EC-diesel on emissions from light heavy-duty diesel vehicles." Environmental Science \& Technology 36, no. 8 (2002): 1686-1691. https://doi.org/10.1021/es0112310

[8] Kousoulidou, Marina, Georgios Fontaras, Leonidas Ntziachristos, and Zissis Samaras. "Biodiesel blend effects on common-rail diesel combustion and emissions." Fuel 89, no. 11 (2010): 3442-3449. https://doi.org/10.1016/j.fuel.2010.06.034

[9] Zulkurnai, Fatin Farhanah, Wan Mohd Faizal Wan Mahmood, Norhidayah Mat Taib, and Mohd Radzi Abu Mansor. "Simulation of Combustion Process of Diesel and Ethanol Fuel in Reactivity Controlled Compression Ignition Engine." CFD Letters 13, no. 2 (2021): 1-11. https://doi.org/10.37934/cfdl.13.2.111

[10] Fayad, Mohammed A., and Bashar R. AL-Ogaidi. "Investigation the Morphological Characteristics of the Particulate Matter Emissions from the Oxygenated Fuels Combustion in Diesel Engines." Engineering and Technology Journal 37, no. 10A (2019): 384-390.

[11] Knothe, Gerhard, Christopher A. Sharp, and Thomas W. Ryan. "Exhaust emissions of biodiesel, petrodiesel, neat methyl esters, and alkanes in a new technology engine." Energy \& Fuels 20, no. 1 (2006): $403-408$. https://doi.org/10.1021/ef0502711

[12] Fayad, Mohammed A. "Investigating the influence of oxygenated fuel on particulate size distribution and NOX control in a common-rail diesel engine at rated EGR levels." Thermal Science and Engineering Progress 19 (2020): 100621. https://doi.org/10.1016/i.tsep.2020.100621

[13] Fayad, M. A., Athanasios Tsolakis, D. Fernández-Rodríguez, J. Martin Herreros, F. J. Martos, and M. Lapuerta. "Manipulating modern diesel engine particulate emission characteristics through butanol fuel blending and fuel injection strategies for efficient diesel oxidation catalysts." Applied Energy 190 (2017): 490-500. https://doi.org/10.1016/i.apenergy.2016.12.102

[14] Happonen, Matti, Tero Lähde, Maria E. Messing, Teemu Sarjovaara, Martti Larmi, L. Reine Wallenberg, Annele Virtanen, and Jorma Keskinen. "The comparison of particle oxidation and surface structure of diesel soot particles between fossil fuel and novel renewable diesel fuel." Fuel 89, no. 12 (2010): 4008-4013. https://doi.org/10.1016/j.fuel.2010.06.006

[15] Fayad, Mohammed A., Athanasios Tsolakis, and Francisco J. Martos. "Influence of alternative fuels on combustion and characteristics of particulate matter morphology in a compression ignition diesel engine." Renewable Energy 149 (2020): 962-969. https://doi.org/10.1016/j.renene.2019.10.079

[16] Westbrook, Charles K., William J. Pitz, and Henry J. Curran. "Chemical kinetic modeling study of the effects of oxygenated hydrocarbons on soot emissions from diesel engines." The Journal of Physical Chemistry A 110, no. 21 (2006): 6912-6922. https://doi.org/10.1021/ip056362g

[17] Mühlbauer, Wolfgang, Christian Zöllner, Sebastian Lehmann, Sebastian Lorenz, and Dieter Brüggemann. "Correlations between physicochemical properties of emitted diesel particulate matter and its reactivity." Combustion and Flame 167 (2016): 39-51. https://doi.org/10.1016/i.combustflame.2016.02.029

[18] Song, Juhun, Kraipat Cheenkachorn, Jinguo Wang, Joseph Perez, André L. Boehman, Philip John Young, and Francis J. Waller. "Effect of oxygenated fuel on combustion and emissions in a light-duty turbo diesel engine." Energy \& Fuels 16, no. 2 (2002): 294-301. https://doi.org/10.1021/ef010167t

[19] Yehliu, Kuen, Randy L. Vander Wal, Octavio Armas, and André L. Boehman. "Impact of fuel formulation on the nanostructure and reactivity of diesel soot." Combustion and Flame 159, no. 12 (2012): 3597-3606. https://doi.org/10.1016/i.combustflame.2012.07.004

[20] Fayad, Mohammed A., Jose M. Herreros, Francisco J. Martos, and Athanasios Tsolakis. "Role of alternative fuels on particulate matter (PM) characteristics and influence of the diesel oxidation catalyst." Environmental Science \& Technology 49, no. 19 (2015): 11967-11973. https://doi.org/10.1021/acs.est.5b02447 
[21] Vander Wal, Randy L., and Aaron J. Tomasek. "Soot oxidation: dependence upon initial nanostructure." Combustion and Flame 134, no. 1-2 (2003): 1-9. https://doi.org/10.1016/S0010-2180(03)00084-1

[22] Abood, Marwa K., Mohammed A. Fayad, Hind A. Al Salihi, and Hassan Ali Abdulmajeed Salbi. "Effect of ZnO nanoparticles deposition on porous silicon solar cell." Materials Today: Proceedings 42 (2021): 2935-2940. https://doi.org/10.1016/j.matpr.2020.12.771

[23] Neer, Adam, and Umit O. Koylu. "Effect of operating conditions on the size, morphology, and concentration of submicrometer particulates emitted from a diesel engine." Combustion and Flame 146, no. 1-2 (2006): 142-154. https://doi.org/10.1016/i.combustflame.2006.04.003

[24] Pickett, Lyle M., and Dennis L. Siebers. "Soot in diesel fuel jets: effects of ambient temperature, ambient density, and injection pressure." Combustion and Flame 138, no. 1-2 (2004): 114-135. https://doi.org/10.1016/i.combustflame.2004.04.006

[25] Jindal, S., B. P. Nandwana, N. S. Rathore, and Vinod Vashistha. "Experimental investigation of the effect of compression ratio and injection pressure in a direct injection diesel engine running on Jatropha methyl ester." Applied Thermal Engineering 30, no. 5 (2010): 442-448. https://doi.org/10.1016/j.applthermaleng.2009.10.004

[26] Fayad, Mohammed A. "Effect of renewable fuel and injection strategies on combustion characteristics and gaseous emissions in diesel engines." Energy Sources, Part A: Recovery, Utilization, and Environmental Effects 42, no. 4 (2020): 460-470. https://doi.org/10.1080/15567036.2019.1587091

[27] Agarwal, Avinash Kumar, Atul Dhar, Dhananjay Kumar Srivastava, Rakesh Kumar Maurya, and Akhilendra Pratap Singh. "Effect of fuel injection pressure on diesel particulate size and number distribution in a CRDI single cylinder research engine." Fuel 107 (2013): 84-89. https://doi.org/10.1016/j.fuel.2013.01.077

[28] Harris, Stephen J., and M. Matti Maricq. "Signature size distributions for diesel and gasoline engine exhaust particulate matter." Journal of Aerosol Science 32, no. 6 (2001): 749-764. https://doi.org/10.1016/S0021$\underline{8502(00) 00111-7}$

[29] Baritaud, T. A., T. A. Heinze, and J. F. Le Coz. "Spray and self-ignition visualization in a DI diesel engine." SAE Transactions (1994): 1129-1144. https://doi.org/10.4271/940681

[30] Wang, Xiangang, Olawole Abiola Kuti, Wu Zhang, Keiya Nishida, and Zuohua Huang. "Effect of injection pressure on flame and soot characteristics of the biodiesel fuel spray." Combustion Science and Technology 182, no. 10 (2010): 1369-1390. https://doi.org/10.1080/00102201003789139

[31] Al Salihi, Hind A., Mohammed A. Fayad, Michael Slepchenkov, and Vladislav Shunaev. "Nanoscale oscillator on the base of single-walled carbon nanotube with internal fullerenes C36 and C80." In Saratov Fall Meeting 2019: Laser Physics, Photonic Technologies, and Molecular Modeling, vol. 11458, p. 1145811. International Society for Optics and Photonics, 2020. https://doi.org/10.1117/12.2564390

[32] Al-Qurashi, Khalid, and André L. Boehman. "Impact of exhaust gas recirculation (EGR) on the oxidative reactivity of diesel engine soot." Combustion and Flame 155, no. 4 (2008): 675-695. https://doi.org/10.1016/i.combustflame.2008.06.002

[33] Zhu, Lei, Wugao Zhang, Wei Liu, and Zhen Huang. "Experimental study on particulate and NOx emissions of a diesel engine fueled with ultra low sulfur diesel, RME-diesel blends and PME-diesel blends." Science of the Total Environment 408, no. 5 (2010): 1050-1058. https://doi.org/10.1016/j.scitotenv.2009.10.056

[34] Mathis, Urs, Martin Mohr, Ralf Kaegi, Andrea Bertola, and Konstantinos Boulouchos. "Influence of diesel engine combustion parameters on primary soot particle diameter." Environmental Science \& Technology 39, no. 6 (2005): 1887-1892. https://doi.org/10.1021/es049578p

[35] Jung, Yongjin, Joonsik Hwang, and Choongsik Bae. "Assessment of particulate matter in exhaust gas for biodiesel and diesel under conventional and low temperature combustion in a compression ignition engine." Fuel 165 (2016): 413-424. https://doi.org/10.1016/i.fuel.2015.10.076

[36] Saxena, Vishal, Niraj Kumar, and Vinod Kumar Saxena. "A comprehensive review on combustion and stability aspects of metal nanoparticles and its additive effect on diesel and biodiesel fuelled $\mathrm{Cl}$ engine." Renewable and Sustainable Energy Reviews 70 (2017): 563-588. https://doi.org/10.1016/i.rser.2016.11.067

[37] Macias, Maria Bogarra, Omid Doustdar, Fayad Fayad, Mirek Wyszynski, Athanasios Tsolakis, and Andrzej Pacek. "Performance of a drop-in biofuel emulsion on a single-cylinder research diesel engine." Combustion Engine PTNSS 3, no. 166 (2016): 9-16. https://doi.org/10.19206/CE-2016-324

[38] Sukjit, E., Jose Martin Herreros, J. Piaszyk, K. D. Dearn, and A. Tsolakis. "Finding synergies in fuels properties for the design of renewable fuels-Hydroxylated biodiesel effects on butanol-diesel blends." Environmental Science \& Technology 47, no. 7 (2013): 3535-3542. https://doi.org/10.1021/es400131j

[39] Lee, Chang Sik, Sung Wook Park, and Sang II Kwon. "An experimental study on the atomization and combustion characteristics of biodiesel-blended fuels." Energy \& Fuels 19, no. 5 (2005): 2201-2208. https://doi.org/10.1021/ef050026h 
[40] Zhang, Jie, Kebin He, Xiaoyan Shi, and Yu Zhao. "Comparison of particle emissions from an engine operating on biodiesel and petroleum diesel." Fuel 90, no. 6 (2011): 2089-2097. https://doi.org/10.1016/i.fuel.2011.01.039

[41] Zhu, Mingming, Hendrix Y. Setyawan, Zhezi Zhang, and Dongke Zhang. "Effect of n-butanol addition on the burning rate and soot characteristics during combustion of single droplets of diesel-biodiesel blends." Fuel 265 (2020): 117020. https://doi.org/10.1016/j.fuel.2020.117020

[42] Wei, Long, Chun Shun Cheung, and Zhi Ning. "Influence of waste cooking oil biodiesel on combustion, unregulated gaseous emissions and particulate emissions of a direct-injection diesel engine." Energy 127 (2017): 175-185. https://doi.org/10.1016/i.energy.2017.03.117

[43] Choi, Seuk Cheun, Hyun Gu Roh, Kwan Soo Lee, and Chang Sik Lee. "Effects of fuel injection parameters on the morphological characteristics of soot particulates and exhaust emissions from a light-duty diesel engine." Energy \& Fuels 24, no. 5 (2010): 2875-2882. https://doi.org/10.1021/ef901561u

[44] Lapuerta, Magin, José Rodríguez-Fernández, and John R. Agudelo. "Diesel particulate emissions from used cooking oil biodiesel." Bioresource Technology 99, no. 4 (2008): 731-740. https://doi.org/10.1016/i.biortech.2007.01.033

[45] Hwang, Joonsik, Yongjin Jung, and Choongsik Bae. "Particulate morphology of waste cooking oil biodiesel and diesel in a heavy duty diesel engine." In International Conference on Optical Particle Characterization (OPC 2014), vol. 9232, p. 92320B. International Society for Optics and Photonics, 2014. https://doi.org/10.1117/12.2063599

[46] Qu, Lei, Zhong Wang, Huihui Hu, Xiaoxiao Li, and Yang Zhao. "Effects of butanol on components and morphology of particles emitted by diesel engines." Research of Environmental Sciences 28, no. 10 (2015): 1518-1523.

[47] Gumus, Metin, Cenk Sayin, and Mustafa Canakci. "The impact of fuel injection pressure on the exhaust emissions of a direct injection diesel engine fueled with biodiesel-diesel fuel blends." Fuel 95 (2012): $486-494$. https://doi.org/10.1016/i.fuel.2011.11.020

[48] Rakopoulos, C. D., K. A. Antonopoulos, and D. C. Rakopoulos. "Experimental heat release analysis and emissions of a HSDI diesel engine fueled with ethanol-diesel fuel blends." Energy 32, no. 10 (2007): 1791-1808. https://doi.org/10.1016/i.energy.2007.03.005

[49] Hulwan, Dattatray Bapu, and Satishchandra V. Joshi. "Performance, emission and combustion characteristic of a multicylinder DI diesel engine running on diesel-ethanol-biodiesel blends of high ethanol content." Applied Energy 88, no. 12 (2011): 5042-5055. https://doi.org/10.1016/i.apenergy.2011.07.008

[50] Dhahad, Hayder A., and Mohammed A. Fayad. "Role of different antioxidants additions to renewable fuels on NOX emissions reduction and smoke number in direct injection diesel engine." Fuel 279 (2020): 118384. https://doi.org/10.1016/i.fuel.2020.118384

[51] Di, Yage, Chun Shun Cheung, and Zuohua Huang. "Experimental investigation on regulated and unregulated emissions of a diesel engine fueled with ultra-low sulfur diesel fuel blended with biodiesel from waste cooking oil." Science of the Total Environment 407, no. 2 (2009): 835-846. https://doi.org/10.1016/j.scitotenv.2008.09.023

[52] Ren, Yi, Zuohua Huang, Haiyan Miao, Yage Di, Deming Jiang, Ke Zeng, Bing Liu, and Xibin Wang. "Combustion and emissions of a DI diesel engine fuelled with diesel-oxygenate blends." Fuel 87, no. 12 (2008): 2691-2697. https://doi.org/10.1016/j.fuel.2008.02.017

[53] Ajav, E. A., Bachchan Singh, and T. K. Bhattacharya. "Performance of a stationary diesel engine using vapourized ethanol as supplementary fuel." Biomass and Bioenergy 15, no. 6 (1998): 493-502. https://doi.org/10.1016/S09619534(98)00055-5

[54] Ren, Yi, Zuohua Huang, Deming Jiang, Liangxin Liu, Ke Zeng, Bing Liu, and Xibin Wang. "Combustion characteristics of a compression-ignition engine fuelled with diesel-dimethoxy methane blends under various fuel injection advance angles." Applied Thermal Engineering 26, no. $4 \quad$ (2006): $327-337$. https://doi.org/10.1016/i.applthermaleng.2005.07.009

[55] Fayad, Mohammed A., and Hayder A. Dhahad. "Effects of adding aluminum oxide nanoparticles to butanol-diesel blends on performance, particulate matter, and emission characteristics of diesel engine." Fuel 286 (2021): 119363. https://doi.org/10.1016/i.fuel.2020.119363

[56] Fayad, Mohammed A. "Effect of fuel injection strategy on combustion performance and NO x/smoke trade-off under a range of operating conditions for a heavy-duty DI diesel engine." SN Applied Sciences 1, no. 9 (2019): 1-10. https://doi.org/10.1007/s42452-019-1083-2 